\title{
Study on the Problems and Legal Countermeasures of Internet Religion in the "Belt and Road Initiative"
}

\author{
Yan-lin LI, Hui-juan MA, Peng NAI and Wei-hua XIE* \\ Law School of Yunnan University of Finance and Economics, Yunnan, China \\ ${ }^{*}$ Corresponding author
}

Keywords: "Belt and Road Initiatives"; Internet Religion; Legal Countermeasures.

\begin{abstract}
In 2013, China proposed the "Belt and Road Initiatives" strategic to actively develop economic partnerships with countries along the route. The religious characteristics of the countries along the route are obvious. Religious culture has become the country's cultural soft power. Religion plays an irreplaceable role in the process of the "Belt and Road Initiatives", but also has negative and positive effects. The combination of the Internet and religion has become increasingly close, and Internet religion has become an important means for the dissemination of religious culture. In the process of implementing the "Belt and Road Initiatives", the religious risks brought by the Internet religion cannot be ignored. Through the study of the relationship between the "Belt and Road Initiatives" and religion, this paper analyzes the religious risks in the Internet during the construction of the "Belt and Road Initiatives", and proposes legal measures for the smooth implementation of the "Belt and Road Initiative" so that religions can play an active role in promoting the friendly exchanges between China and the countries along the route.
\end{abstract}

\section{Introduction}

In recent years, many netizens have reported to the departments concerned that a certain brand store provides the issue of spreading Falun Gong and Almighty God's cult APP. Cultists infiltrate the masses of our country with cults through a network of mobile platforms and other means. China has taken measures to promote the application of cults, which has been ordered to be demolished by the competent authorities. December 2016 Ministry of Industry and Information Technology of the People's Republic of China released documents, the provision stress: "Internet service providers that provide mobile intelligent terminal application software distribution services to manufacturing enterprises shall not provide or distribute mobile intelligent terminal applications that contain content that promotes cults." And the provision implemented on July 1, 2017. Internet religion has become a major new type of media for the development and spread of religions, so that religious believers are faster and more likely to participate in religious activities, and promote the development of religion in our country. However, the rapid development of religious network also brings risks. Although Ministry of Industry and Information Technology of the People's Republic of China issued the provision curbs cult APP propaganda incident continues, but China has not yet promulgated special laws and provisions on the regulation of issues on the Internet religion, the legal system has not yet been established for the management and regulation of Internet religion.

The "Belt and Road Initiatives" is an important strategic move under the new situation in our country. In the great strategic process of implementing the "Belt and Road Initiatives" in China, positive religious culture plays an important role in China's economic, political and cultural development. It can promote close ties and common development between our country and the countries along the "Belt and Road Initiatives". However, in the healthy development of religious groups and places of religious activity, criminals such as cultists and religious extremists are taking advantage of this strategic opportunity, through the establishment of illegal religious organizations, in particular, the concept of religious extremism is spread through the Internet platform, attempting to split our country, destroy the friendly exchanges between China and the countries along the "Belt and Road", and impede the strategic process of building the "Belt and Road Initiatives " in our country.

April 22-23, 2016, President Xi Jinping pointed out that in the National Religious Work 
Conference: "We must attach great importance to Internet religious issues." [1] Under the new situation, religion should be more actively adapt to socialism, and coordination with the "Belt and Road Initiatives". This article will enable the religious forces to promote strategic development under the "Belt and Road Initiative", combined with the religious situation the country along the "Belt and Road", emphasize the close relationship between religion and the "Belt and Road Initiatives", in-depth study of the present situation of the network religion in our country and the problems that arise, to explore the regulation of religious risks on the Internet from a legal point of view, resisting the religious infiltration of evil forces outside China, strengthen the legal publicity of religion, establish and improve the regulatory legal system of Internet religion, promote the healthy religious development in China and other countries along the "Belt and Road Initiatives", religious people in various countries and the people are friendly to each other, and promote the successful implementation of the "Belt and Road Initiatives".

\section{The Relationship Between Religion and the "Belt and Road Initiatives"}

Religion, as a spiritual pillar of religious people, is an irresistible and long history of spiritual civilization. In the strategic process of implementing the "Belt and Road" in our country, religion is inseparable from politics and economic construction to play its unique and positive role. The countries along the "Belt and Road Initiatives" mainly believe in Buddhism, Christianity, and Islamism. In the circumstances of different national conditions and development progress in different countries, religious issues seem to be complicated. The Republic of Kazakhstan, Turkmenistan and other six countries in Central Asia mainly believe in Islamism; in addition to the Republic of Albania, Bosnia and Herzegovina, the 16 Central and Eastern European countries are mainly believe in Catholic Church and Orthodox Church; most of the 11 Southeast Asian countries are multi-religious countries. The 18 provinces and autonomous regions delineated by our country along the "Belt and Road Initiatives" are located in the more ethnic minorities in the southwestern and northwestern regions, which are more pronounced religious beliefs, more opportunities to connect with foreign countries and cultural exchange among peoples. It will promote the implementation of the "Belt and Road Initiatives" and make the religious culture of all ethnic groups in various countries along the line colorful. In the implementation of the "Belt and Road Initiatives" strategy in China, religion can play its unique and active role, in particular, the people of our country who believe in Islam can gain in-depth understanding and exchanges with Muslims in Central Asia, Southeast Asia and other countries. The Deputy Secretary-General of the Chinese Islamic Association, Yang Zhibo, believes that the construction of the "Belt and Road Initiatives" should be helped through Islamic cultural exchanges [2]. Due to the existence of religious social groups, religious parties and religious believers, religion still has a major impact on political life. Religion not only has a positive impact but also risks in the process of building the "Belt and Road Initiatives". For example, some countries regard religion as a state religion, in certain circumstances, religious conflicts with political, economic and cultural factors in these countries raise religious risks. We pay attention to the mutual exchange of religions and cultures among various nationalities in various countries, but for this reason, national contacts may lead to obstacles and conflicts, leading to religious disputes and risks.

Religious risks due to different religious beliefs, religious cultures and other issues, China should pay attention to avoidance in the process of building the "Belt and Road Initiatives". "Religious risk refers to the degree of undesired events caused by religion and the magnitude of this uncertainty. Religion itself is not a risk, but it may be a cause of unsatisfactory events." [3] The issue of religious risk not only includes the issue of religious beliefs, but also religious group activities and religious property. Our country is committed to actively and healthily guiding the religion development, and orderly regulating religious administration. But in the past 10 years, many new problems and circumstances have emerged in the religious field, such as commercialization of places of religious activity, the spread of religious terrorism by Internet religions, the infiltration of overseas religious extremism, and religious heritage. Especially for the benefit of today's science and technology and the connection of global Internet, the development of Internet religion is rapid 
and huge. The communalization of information and the timeliness of information have provided new avenues for religious extremists and for the evil forces outside the country. "The Regulations on Religious Affairs" were revised on June 14, 2017, and the length of religious affairs is specified in detail, requiring religious groups and places of religious activity to maintain religious features. And according to the current situation of the spread of religious extremism in some countries and regions, China is required to pay more attention to the prevention and crackdown on religious extremists and to punish religious extremists with legal means. The revision of "The Regulations on Religious Affairs" provided the legal support and guarantee for our further administration and regulation of religious affairs, and "the General Principles of Civil Law" affirmed the legal status of religious groups and places of religious activities, the development of religious groups and places of religious activity in our country more adapts to the new situation in the "Belt and Road" construction and socialist construction. However, in recent years, new problems and situation have emerged in the network religions, but China has not yet put in place special laws and regulations to regulate it. In the process of building the "Belt and Road Initiative", the clashes between our religions and other countries along the routes will inevitably lead to new situations and new problems. The Internet is the quickest tool of information dissemination, but it is also a tool used by religious extremists. In order to better create a peaceful, co-existing and harmonious relationship of friendly exchanges among all nations and China and other countries along the country make progress on economic, political and cultural, our country should recognize the religious risk, manage and standardize the development of network religion, curb and prevent infiltration of religious extremism. Play a positive role in religion, enrich people's spiritual world, and learn from each other positive and excellent cultural essence, so that religions of all ethnic groups in all countries will be developed in a healthy and orderly manner.

\section{The Overview of Network Religion}

\subsection{The general introduction of network religion}

The Internet is as the media of a kind of new times, and its ageing and spatiality is that any traditional media is incomparable. Because of the birth and the development of internet, the massive information has prompted China to keep pace with the times and connected mutually with the world. Religion is also integrated with the Internet, using the advantages of the fast and wide spread of the Internet, to innovate the forms of communication with religions, disseminating religious doctrines, messages in the field of religion, and related religious ceremonial activities to form a trend of network religion. Although network religions are new things that have emerged in the past 20 years or more, from the perspective of religious communication, network religion is nothing more than the result of the evolution of traditional religions, and it is an innovation of communication channels [4].

Network religions mainly use websites, virtual communities and instant messaging software to conduct religious activities in Internet. The combination of religion and the Internet has shaped the network religion's unique features: the high openness of network religion. From a time and space perspective, one of the characteristics of the network is the lack of space and time [5]. Religious subjects and religious believers spread religious doctrines, publish religious publications, and organize online religious activities through websites and software platforms. The wider coverage of religious networks benefits from the Internet-oriented features of the public, religious and unbelieving people have access to religious content, different from the traditional way that is centralized propagation.

The rise of network religion undoubtedly plays a positive role in the development of religion. It not only is confined to domestic, and it has more international characteristic. Since the $90 \mathrm{~s}$, most countries in the world have established network religion. For example, the United States is a country with a long history of network religion, and its religious network has spread to 211 countries and regions in the world by 2013. According to the Chinese Religious Survey (CRS) report 2015, in our country, "10\% of the places use online preaching" and "Buddhism is the highest 
percentage of religions using the Internet (14\%)". Network religion has also become an important way of religious propagation in our country. At this stage, China's most widely used social networking platform: Weibo. According to the third quarter of 2017 Weibo financial statements data: as of September 2017, the total number of monthly active users of Weibo was 376 million [6], Weibo has become one of the most common ways to acquire and exchange information in daily life, religion is also spread the information through the Weibo. The research group of "The legalization of religious work under the opportunity of compiling civil code" belongs to the Western projects supported by National Social Science Foundation and makes statistics: in the Weibo platform, the number of religion registered users is 258,908, the number of Buddhist registered users is 258,908, and the number of Christian registered users is 10098, a total of 284,562. As shown in Figure 1:

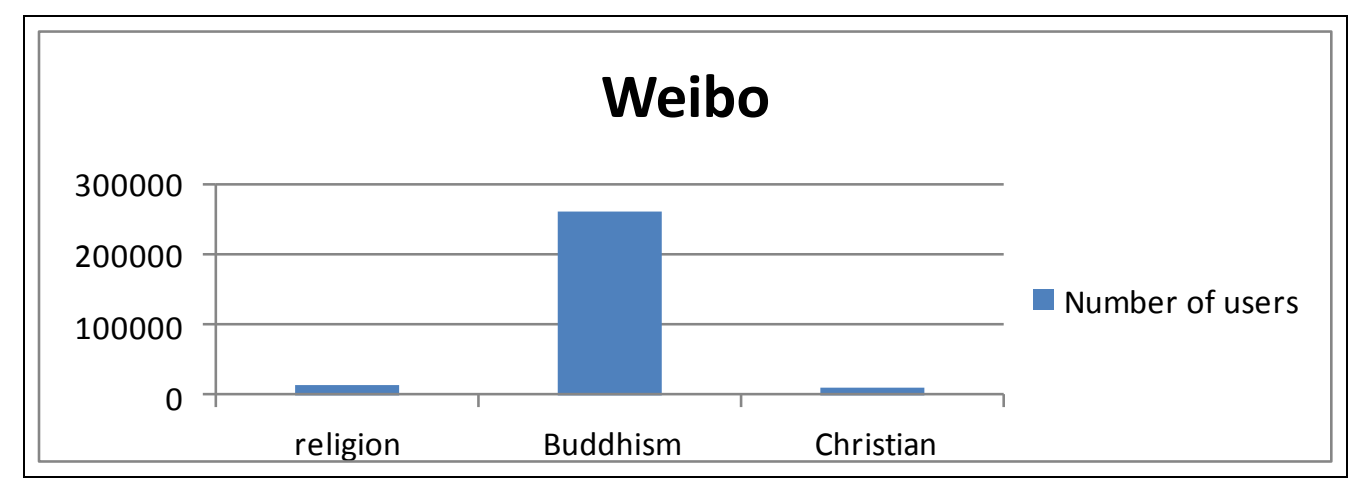

Figure 1. Religious-related registered users in Weibo

Weibo monthly active users in 2017 increased by $27 \%$ compared to the same period in 2016 , and the number of users registered for religious and related religious information increases by 70,000 annually. If calculated by this ratio and growth rate, the amount of information disseminated by religious culture in Weibo cannot be predicted.

Religious culture as a country's influential factor, network religion is the fastest way to spread religious culture. U.S. Graham Gospel Society considered "God increases his glory through the internet" [7], network religion promotes the spread of religious ideas and guides believers to learn doctrines, positively transfers religious ideas that adapt to socialism, further strengthens national cohesion, and enhances China's overall national strength. The countries along the "Belt and Road Initiative" also develop the country's religious culture through the Internet. The "Belt and Road" Strategic Cooperation between West Asia countries: Israel, "In the past decade, there has been a marked increase in religious websites and activities online within the sphere of the Israeli Internet." [8] Religious and cultural exchanges between China and the countries along the "Belt and Road Initiatives" are not limited to face-to-face communication. They can promote religious culture and characteristics of our country to countries along the route through online religions, and strengthen the exchange of religious feelings between countries.

\subsection{The religious risk of Internet in the "Belt and Road Initiatives"}

In the implementation of the "Belt and Road Initiatives" strategy, the use of the Internet as a medium of communication has enhanced the exchange of information between China and countries along the route and strengthened the internal and external relations of religious sects. However, while affirming the development of network religion, it should also be noted that it has a negative effect on the implementation of strategy. Many problems have emerged in network religions, for example, in recent years, most netizens have received information on cults such as Falun Gong and Almighty God from a certain brand store; the WeChat application platform has also been used by non-religious activity site account subjects to publish links to fraudulent "religious donation" content. There are three main problems in network religion:

There is a loophole in the management of network religious operating platform. Religious subjects promote religious culture through various channels and activities on the Internet, such as setting up religious colleges online, publishing religious publications, etc. In online religious colleges, religious people can obtain relevant certificates through the study of online courses, which 
greatly facilitates religious believers to enhance their beliefs. However, the contents of teaching courses offered by some online religious schools are illegal and contravene socialism, and online religious publications, including the publication of articles, are still valid. With the rise of religious networks, the identification of religious teaching staff has broken through the limits. There have been many Internet religious staff, and the qualifications of online religious staff are difficult to determine. As for the problems of these network religions, China has not yet formulated specific laws and regulations for this phenomenon. In the process of building the "Belt and Road Initiatives", the existing practical problems of network religion are not effectively monitored, which will affect the smooth exchange of religious culture between our country and the countries along the route, and the smooth implementation of our country's strategy.

Overseas evil forces infiltrate China through cyber religion. In the context of economic globalization, the trend of China's religious exchanges has become increasingly apparent. As a powerful strategic resource at the ideological level, religion is often used by Western hostile forces and Islamic extremist forces, and infiltrates our country in the name of religion. In the construction of the "Belt and Road Initiatives", involving economic, political, and cultural interests, China with hard power is already a stronger country in the world, but, as a religion of cultural soft power, there are still deficiencies in Western countries. Religious extremism is a product of international and domestic political issues, often entwined with ethnic conflicts and conflicts between nations [9]. The research group of "The legalization of religious work under the opportunity of compiling civil code" belongs to Western projects supported by National Social Science Foundation and made survey shows: there are 810 college students, aged under 30, including 203 religious activities, accounting for $25.1 \%$ of the total, received 462 religious doctrines and religion-related content pushed by online religions, accounting for $57 \%$ of the total, and 260 students received cult propaganda, religious extremism or religious terrorism ideas, accounting for $32 \%$ of the total. Western hostile forces and religious extremists have used network religious exchanges to publicize the reactionary separatist extremist ideology and to undermine China's national unity. In recent years, religions outside the country have spread religions, especially teachers and students and other people in universities in our country, and have disseminated the lifestyle and values of Western developed countries, named "Gospel Project", it is actually using evil religious ideas to block China's mainstream values rather than to spread religion as a pure spiritual civilization. Western hostile forces and Islamic extremist forces will use the opportunity of cooperation between China and the countries along the route to incite terrorists to undermine and hinder the construction of the "Belt and Road Initiatives", affecting the friendly exchanges between our country and the various nations.

Criminals use network religions to infringe the legitimate rights and interests of citizens. In the area of network religion, "A religious leader is no longer the sole source of information in a certain sense. Everyone can publish religious culture-related information. Everyone can be a preacher, and everyone can also be an apostle." [10] It is precisely because of the open and virtual nature of network religion that it provides a channel for criminals. There are many religious, Buddhist and Christian religions registered on the WeChat software platform in China. However, there are many non-religious people or religious extremists who use the WeChat public platform to send illegal links to the masses. Under the banner of religion, they deceive citizens' property and even threaten their personal safety, and damage the legal rights of religious subjects and WeChat users. This phenomenon does not only exist in WeChat. Non-religious people or religious extremists have deceived the people's property and spread extremist ideology through the establishment of religious websites, religious blogs, registered religious public accounts, and groups. If these phenomena are not curbed in a timely measure, it will inevitably affect the stability of our country's society and further affect the process of cooperation between our country and the countries along the "Belt and Road Initiatives “.

\section{Legal Countermeasures of Internet Religious Risk}

Network platform for the spread and development of religion is conducive to strengthening 
communication among all ethnic groups in various countries, and managing religious affairs on the Internet in accordance with the law. It is an important guarantee for China to ensure network security and ideological security during the construction of the "Belt and Road Initiative". China should prevent Internet religious issues from becoming risks on the road to construction and undermine the smooth implementation of our country's strategy. According to the latest revision of Article 47 and 48 in China, "Regulations on Religious Affairs" stipulated that engaging in religious information services on the Internet should be approved by the religious affairs department of the people's government at or above the provincial level, and the contents of Internet religious information services should be in compliance with relevant laws, regulations, rules, and religious affairs management regulations. This is a major step forward for China's religious management of the Internet. However, the problem of online religion has its own particularity and complexity. In the construction of the "Belt and Road Initiatives", special legal provisions should be issued in response to network religious issues, to strengthen the management of online religious communication and establish a sound regulatory legal system.

\subsection{Accelerate the establishment and improvement of a regulatory system for network religions}

Our country faces the problems of the existence of online religions, the content of online teaching classes, and religious publications on the Internet that violate the law and religious extremists posing as religious staff. China should establish a legal system of network religious supervision, formulate systematic rules for online religious access, online publications, rules for operating online platforms, and legal responsibilities that should be borne in violation of regulatory provisions, including legal provisions concerning online religious affairs. Improve the countermeasures for the religious risks of the Internet, establish a standard for strict platforms when the religious network platform is established; during the operation of the online religious platform, it strictly supervises the content of religious culture released by the platform; if there is any misuse of the Internet religious platform, the continued operation of the platform should be banned in a timely manner, and relevant criminals must be bear legal responsibility.

\subsection{Resist the religious infiltration of evil forces from abroad, and strengthen religious rule of law propaganda}

In the implementation of the "Belt and Road Initiatives" in our country, government departments should actively guide the masses to express their opinions on the Internet platform and respect the religious culture and customs of the countries along the route. Our country can coexist with the countries along the country through the power of religious culture. However, we must also be vigilant against the evil forces outside the country in the name of religion to promote cults and separatist ideology to our people. China's relevant administrative departments and judicial branch such as State Administration for Religious Affairs of P.R.C, Ministry of Industry and Information Technology of the People's Republic of China, the Supreme People's Court of the People's Republic of China, and the Supreme People's Procuratorate of the People's Republic of China and other official websites should vigorously carry out online learning publicity for the "the General Principles of Civil Law" and the newly revised "Regulations on Religious Affairs". Strengthen religious rule of law propaganda on the Internet through audio, video and other forms. To make the various forms of the Internet platform for the construction of the "Belt and Road Initiatives" strategic services, so that the development of network religious platform more legitimate and rationalized, more adaptable to socialist modernization.

\section{References}

[1] Information on http://www.xinhuanet.com/politics/2016-04/23/c_1118716540.htm.

[2] Y. G. Wu: The Religious Cultures in the World, 2017, No. 01, pp. 004.

[3] H. Y. Wang: China Religion, 2017, No. 03, pp. 66. 
[4] H. Zhang, Z. P. Zhang: The Religious Cultures in the World, 2016, No. 04, pp. 021.

[5] C. A. Zhang: Marxist atheism research, November 3, 2015, Vol. 2, pp. 279-289.

[6] Information on http://www.useit.com.cn/thread-17562-1-1.html.

[7] X. Jin: Beijing Forum (2015) Harmony and Common Prosperity of Civilizations - Different Roads and Common Responsibilities: The United States, the United States, the United States, and the Review and Prospect of the Exchange and Cooperation of Human Civilization, Beijing, November 11-6, 2015, pp. 215-226.

[8] Heidi Campbell: Israel Affairs. DOI: 2011. 10.1080/13537121.2011.584664.

[9] Y. F. MA: China Religion, 2017, No. 02, pp. 46.

[10] J. Sun: Journals of Huaihai Institute of Technology, 2014, No. 2, pp. 67. 